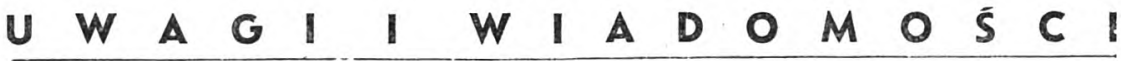

\section{BIULETYN STUDIÓW O KARAITACH}

W czasie trwania XXIX Kongresu Orientalistów w Paryżu (16-22 lipca 1973 r.) ogłoszono komunikat o założeniu nowego periodyku naukowego w formie biuletynu: Bulletin d'études karaïtes. Wiadomo, że w VIII w. na terenie Iraku wyodrębniła się z judaizmu religia karaicka. Stanowiła ona reakcję przeciw talmudyzmowi; uznaje ona wyłącznie Stary Testament (gł. Dekalog), odrzucając wszystkie późniejsze komentarze judaistyczne wraz z ustną tradycją. W w. VIII-X religia karaicka rozszerzyła się w Mezopotamii, Syrii, Bizancjum, Persji i państwie chazarskim, po którego upadku przyjęła się wśród części ludności tureckiej.

Od dłuższego czasu odczuwano w świecie nauki potrzebę publikacji poświęconych problemowi karaizmu. Dotychczasowe bowiem artykuły, skupiające uwagę na życiu poszczególnych małych wspólnot karaickich, ukazywały się sporadycznie $i$ to $w$ językach lokalnych. Nowo odkryte dokumenty i powstanie nowego domu wydawniczego w Paryżu stworzyły sprzyjające warunki do wydawania nowego biuletynu, poświęconego temu problemowi.

Biuletyn ma za cel stworzyć centrum zainteresowań religią karaicką i być miejscem wymiany idei i dokumentacji, dostępnym dla wszystkich zainteresowanych. Mają się w nim ukazywać artykuły historyczne, literackie, filozoficzne, lingwistyczne, prawnicze, socjologiczne, etnograficzne itp. Szczególną uwagę zwróci biuletyn na problemy bibliograficzne. Artykuły do biuletynu będą przyjmowane w glównych językach, używanych w publikacjah naukowych.

W skład komitetu redakcyjnego wchodzą: Paolo S a c chi, Simon S z ys z m a n, Giuliano Tamani. Adres Wydawnictwa:

LIBRAIRIE ORIENTALISTE PAUL GEUTHNER

$$
\text { 12, RUE VAVIN - PARIS (VIe) }
$$

